\title{
Tüketicilerin Türk Kahvesi Hakkında Bilgiye Sahip Olma Algı Seviyelerinin Demografik Özelliklere Göre Karşılaştırılması̊ ${ }^{1}$
}

\author{
Dr. Öğr. Üyesi Erdem TEMELOĞLU \\ Çanakkale Onsekiz Mart Üniversitesi, Ayvacık Meslek Yüksekokulu \\ etemeloglu@comu.edu.tr \\ https://orcid.org/0000-0001-8572-9172 \\ Dr. Öğr. Üyesi Defne AKDENIZZ \\ Çanakkale Onsekiz Mart Üniversitesi, Ayvacık Meslek Yüksekokulu \\ defneakdeniz@comu.edu.tr \\ https://orcid.org/0000-0001-8572-5438 \\ https://doi.org/10.37847/tdtad.731075
}

\section{Özet}

Yapılan araştırmalar göstermektedir ki, son derece köklü bir geçmişe sahip olan ve Türk mutfağının en önde gelen içeceklerinden biri olan Türk kahvesi, Türkiye'de küresel kahve zincirlerinde Batılı yöntemlerle hazırlanan yeni kahvelere göre tüketiciler tarafından daha az tercih edilmekte ve Türk kahvesine gösterilen ilgi azalmaktadır. Türk kahvesine gösterilen ilginin yeniden canlandırılabilmesi için Türk kahvesine önem verilmeli ve Türk kahvesinin tarihi, yapısı, özellikleri, hazırlanma ve servis süreçleri ile ilgili bilgi sahibi olunmalıdır. Bu çalışmanın amacı Türk kahvesi hakkında tüketicilerin bilgi düzeyini ölçmeyi ve bu bilgi düzeyinin demografik değișkenlerle karşılaștırılmasını amaçlamaktadır. İlerleyen dönemlerde Türk kahvesi üzerine yapılacak bir dizi araştırmanın ön çalışmasıdır. Geliştirilen anket formu ile 'kolayda örnekleme yöntemi' kullanılarak 528 kişiye ulaşılmıştır. Araştırma, Türk kahvesi üzerine sahip olunan bilgi düzeyi algısının yaşa, mesleğe ve gelir durumuna göre bir değişiklik göstermediğini saptarken, kadınların, eğitim düzeyi daha yüksek grupların ve daha sık kahve tüketen tüketicilerin Türk kahvesi hakkında daha fazla bilgiye sahip olduklarını düşündüklerini ortaya koymuştur. Bu sonuçlar Türk kahvesi gibi önemli bir mirasın sürdürülebilmesi yönünde atılabilecek adımlar için öncül teşkil etmekte ve ilerleyen çalışmalar için bir hareket noktası oluşturmaktadır.

Anahtar Kelimeler: Türk Kahvesi, Tüketici, Algılanan Bilgi Düzeyi, Demografik Değişkenler

\section{Evaluation of Turkish Coffee Consumers' Perception of Knowledge Through Consumer Demografics}

\begin{abstract}
Researches show that Turkish coffee, which has a very deep-rooted history and is one of the leading beverages of Turkish cuisine, is less preferred than new coffee prepared by Western methods in global coffee chains and interest in Turkish coffee is decreasing. Turkish coffee should be given importance in order to revive the interest shown in Turkish coffee. It should be known about the history, structure, properties, preparation and service processes of Turkish coffee. The aim of this study is to measure the level of knowledge about Turkish coffee and to compare this level of

${ }^{1}$ Bu makale, 16-19 Ekim 2019 tarihlerinde Eskişehir'de düzenlenen “20. Ulusal Turizm Kongresi”nde sunulan ve bildiriler kitabında yer alan bildirinin geliştirilmiş halidir.
\end{abstract}

July-2020 Vol:5 No:1 International Journal of Turkic World Tourism Studies 
knowledge with demographic variables. As a preliminary study of a series of researches on Turkish coffee in the future, this study measures the level of knowledge perceived by Turkish consumers according to their demographic characteristics and frequency of consumption and the necessity of information. With the developed questionnaire form, 528 people were reached by using 'easy sampling method'. While the research determined that the perception of knowledge level on Turkish coffee did not change according to age, profession and income status, women revealed that they thought that higher education level groups and consumers who consume coffee more information about Turkish coffee. These results constitute a premise for the steps that can be taken to sustain an important heritage such as Turkish coffee and constitute a starting point for further studies.

Key Words: Turkish Coffee, Consumer, Perceived Knowledge Level, Demographic Variables

\section{Giriş}

Kahve, Türk mutfağında ve kültüründe yalnızca bir tüketim maddesi değildir. Ülkemizin tarihini, kültürünü, geleneklerini ve mutfağını bir arada yansıtan etkili bir ulusal kimlik unsuru olmuştur. Hazırlanması, içimi, sunumu ve özel ekipmanlarıyla modern kahvelerden farklılaşmaktadır (Akşit Aşık, 2017). Üzerine deyişler üretilen kız isteme törenlerinin vazgeçilmez içeceği olan, fal bakmaya yarayan Türk kahvesi, Türk toplumu için çok önemli bir kültürel öğe konumundadır (Bulduk ve Süren, 2007).

Yaklaşık 500 yıllık köklü bir tarihe ve kültüre sahip olan Türk kahvesi Türk halkı tarafından halen oldukça fazla sevilerek tüketilmektedir. Günümüzde küresel ve ulusal kahve zincirlerinin farklı kahve çekirdeklerini kullanarak Batıya özgü üretim ve servis yöntemleriyle hazırladıkları farklı lezzetler karşısında popülaritesini ve sosyal statüsünü kaybetmiş gibi görünse de kahve Türk halkı için hala birçok açıdan özel ve eşsizdir (Bulduk ve Süren, 2007). Giritlioğlu ve Gündoğan (2017) Gaziantep ilinde bulunan kafe ve pastane işletmelerini ziyaret eden müşterilerin tüketim alışkanlıklarını belirlemeyi amaçladıkları çalışmalarında, kafe işletmelerinde en çok tercih edilen kahve türünün \%55'lik bir oranla Türk kahvesi olduğunu ileri sürmüşlerdir. Türk Kahvesi Kültürü ve Araştırma Derneği'nin 2017 yılına ait verilerine göre Türkiye'de kişi başı yıllık Türk kahvesi tüketimi 600 gramdır. Bu miktar toplam kahve tüketimine oranlandığında Türk insanının bir yılda tükettiği tüm kahvelerin \%57.9'unun Türk kahvesi olduğu sonucuna varılmaktadır.

Yaygın tüketimi, kültürel ve tarihi önemi ve karşılaştı̆g küreselleşme tehlikesi göz önünde bulundurulduğunda Türk kahvesinin kültürel önemini koruyabilmesi ve bu mirasın kuşaktan kuşağa aktarılabilmesi için bu alanda çalışmalar yapılmalıdır. Bu konuda üniversitelere düşen görevlerden biri Türk kahvesi konusunda bilgi temin etmek ve edinilen bilgiyi yaymaktır. Bu çalışma bahsedilen ihtiyaçtan hareket ederek Türk kahvesinin ürün özellikleri, kavrulması, demlenmesi ve servis edilmesi üzerine sahip olunan bilgi düzeyini ölçmeyi amaçlamaktadır. Bu hedef kapsamında bir dizi inceleme yapacak olan çalışma, ilk aşamada Türk kahve tüketicilerinin sahip olduklarına inandıkları bilgi düzeyini ölçmektedir. Bu kapsamda Türk tüketicilerin, Türk kahvesi hakkında ne kadar bilgi sahibi olduklarını düşündükleri ve bilgi sahibi olmanın gerekliliğine dair inançları saptanmıştır. Ayrıca tüketicilerin Türk kahvesi hakkında sahip olduklarına inandıkları bilgi algısı, onların demografik özellikleriyle (cinsiyet, yaş, eğitim düzeyi, meslek, gelir seviyesi) ve kahve tüketim sıklıkları ile karşılaştırılmıştır. 


\section{Literatür İncelemesi}

14. yüzyılda Etiyopya'da ortaya çıkan kahve, 15.yy'ın sonlarına doğru Araplar tarafından Mekke ve Medine'ye taşınmış, oradan da İstanbul'a getirilmiştir (Heise, 2001; Malaguzzi, 2008). Müslümanlara yasaklanmış olan alkollü içeceklerin yerine içilebilen rahatlatıcı bir içecek olmasından ötürü kahve yaygın olarak rağbet görmüştür. Uykuyu kaçırması, şehveti artırması, halkın toplanıp dilediği gibi konuşabildiği yegâne yerler olması dolayısıyla kahvehanelerin ve kahvenin yasaklanması için nice fermanlar verilmiş olsa da kahve ve kahvehanelerin yaygınlaşmasının önüne geçilememiştir (Gürsoy, 2013). Günümüzde modern görünümlere bürünen geleneksel kahvehanelere, son on beş yılda hızla yaygınlaşan uluslararası ve ulusal kahve zincirleri eklenmiştir. 2012 yılında Türkiye'deki kahve zincirlerinin toplam şube sayısı 400'den az iken, 2017 senesinde en büyük 10 kahve zincirinin sayıs1 927'yi bulmuştur (http://www.karmaliz.com/2017/03/kahve-zincirleri-rekabeti.html). Yalnızca Türk kahvesi ve çay servisi yapan kahvehaneler ürün yelpazelerini genişletmiş, küresel ve yerel kahve zincirleriyle birlikte Türk kahvesi tüketim alışkanlığı köklü biçimde değişmeye başlamıştır. 1980'lerden sonra hazır kahvelerin tüketime girmesiyle birlikte değişime uğrayan geleneksel kahve kültürü, özellikle 2000'li yıllarda Batılı kahve tüketim alışkanlıklarının yaygınlaşmasıyla seçkin bir görünüme bürünmüştür (Akarçay, 2012).

$\mathrm{Bu}$ çalışma, yaptığı yazın araştırması sonucunda Türk kahvesi üzerine yapılan akademik çalışmaların giderek arttığını tespit etmiştir. Bu çalışmalardan bazıları Türk kahvesini içerik açısından ele almakta ve gida mühendisliği, tıp, beslenme, ziraat gibi ana bilim dallarına katkı sağlamaktadır (Sözlü, Yılmaz ve Acar Tek, 2017). Çalışmaların önemli bir bölümünün de Türk kahvesine sosyolojik ve tarihsel açıdan yaklaştığı görülmektedir (Göktaş, 1994; Tansuğ, 1995; Hattox, 1996; Yaşar, 2005; Alagözlü, 2007; Atl1, 2018). Bu çalışmalar Türk kahvesinin keşfinin ve Osmanlı topraklarına girişinin ve kahve içme alışkanlıklarının tarihsel süreçte değişimlerini incelemiş ve sosyal bir birileştirici görevi gören Türk kahvesinin toplumsal aracılığını mercek altına almıștır. Türk kahvesi araștırmalarının yapıldığı bir diğer inceleme boyutu olan tüketim ve tüketim boyutu üzerine odaklanan çalışmaları (Akarçay, 2012; Akşit Așık, 2017; Aydın ve Bakır, 2016; Koç, 2016; Yılmaz vd, 2016) örneklendirmek gerekirse, Akşit Aşık'ın (2017) yaptı̆̆ çalışmada Türk kahvesi tüketiminin toplumsal boyutta yaygın olmasına rağmen, genç ve eğitim düzeyi yüksek tüketicilerin Türk kahvesini daha az tükettikleri tespit edilmiştir. Yılmaz vd. (2016) ise Türk kahvesi tüketim eğilimlerinin belirlenmesini amaçladıkları çalışmalarında, Türk kahvesi içme alışkanlığının daha yüksek olduğunu ancak yeni kahve çeşitlerine olan ilginin hızla arttığını saptamışlardır.

Yapılan yazın araştırması sonucunda Türk kahvesi tüketicisi eğilimlerinin (Y1lmaz vd, 2016; Giritlioğlu ve Gündoğan, 2017) ve tipolojisinin (Tufan, 2019) belirlenmesinin amaçlandığ1 az sayıda çalışma olmasına rağmen Türk kahvesi tüketicinin kahve üzerine sahip olduğu bilgi düzeyine yönelik bir çalışmaya rastlanmamıştır. Daha önce bahsedilen uzun ve köklü tarihi, toplumsal rolü, kültürel işlevi, Türklere özgü bir içecek olması, ulusal kimlik öğesi olması, çok yaygın ve sık olarak tüketilmesi dolayısıyla oldukça önemli olan Türk kahvesi, toplumun yüksek bilgi sahibi olması gereken bir içecektir. Çünkü Türk mutfağı dünyadaki pek çok mutfak gibi diğer dünya mutfaklarından etkilenmektedir. Küreselleşmenin olumsuz etkilerinden kendi payına düşeni alan geleneksel kahvehaneler, yok denecek kadar azalmakta ve geleneksel Türk kahvesi, küresel kahve zincirlerinde küresel yöntemlerle hazırlanıp, servis edilmektedir. Kökleri çok eskilere dayanan zengin Türk mutfağının geleneksel içeceği kahve hakkında bilgi sahibi olmamak, onu küresel etkiler altında silinip yok olma tehlikesine karşı savunmasız bırakmaktadır. Türk kahvesi üzerine 
toplumsal bilgi düzeyinin artması, ürünün standardizasyonu ve sürdürülebilirliğinin önünü açacak, Türk kahvesi kültürünün yaşamasını ve gelecek kuşaklara aktarılmasını sağlayacaktır.

\section{Yöntem}

Çalışmanın temel amacı, tüketicilerin Türk kahvesi hakkındaki bilgiye sahip olma algısını ölçmektir. Tüketicilerin Türk kahvesi hakkındaki bilgiye sahip olma algısı düzeyinin bazı demografik değişkenlere (cinsiyet, yaş, eğitim, meslek, gelir düzeyi) ve Türk kahvesi içme sıklıklarına göre karşılaştırılması çalışmanın alt amacını oluşturmaktadır. Belirlenen bu amaç çerçevesinde, araştırmanın evrenini Türk kahvesi tüketicileri oluşturmaktadır. Çalışmada, zaman, maliyet ve ulaşılabilirlik nedenlerinden dolayı uygulama alanı sınırlandırılarak örneklem belirleme yöntemine gidilmiştir. "Kolayda örnekleme yöntemi” kullanılarak 528 kişi üzerinde araştırma gerçekleştirilmiştir.

Araştırma türüne uygun olarak ikincil verilerin bir taraması ve değerlendirilmesi yapılmış ve buna göre bir anket formu geliştirilmiştir. Anket iki bölümden oluşmaktadır. Anketin birinci bölümünde, tüketicilerin Türk kahvesi hakkında bilgiye sahip olma algılarını ölçmek amacıyla 5'li Likert ölçeğinde üç adet ifade yer almaktadır. Anketin ikinci bölümünde ise, katılımcıların demografik özelliklerini (cinsiyet, yaş, eğitim, meslek, gelir düzeyi) ve Türk kahvesi içme sıklıklarını belirlemek amacıyla altı adet kapalı uçlu soru yer almaktadır.

Araştırmaya katılanların vermiş oldukları cevaplar doğrultusunda elde edilen veriler, sosyal bilimler için geliştirilmiş olan istatistik paket programına aktarılmış ve bu yazılım vasıtasıyla analiz edilmiştir. Araştırmada, yüzde ve frekans analizi, aritmetik ortalama ve standart sapma, t-testi analizi ve ANOVA testi kullanılmıştır.

\section{Bulgular ve Tartışma}

\section{Katılımcıların Demografik Özelliklerine İlişskin Bulgular}

Tablo 1'de katılımcıların demografik özelliklerine ilişkin yüzde ve frekans analizi sonuçları yer almaktadır.

Tablo 1. Katılımcıların Demografik Özelliklerine İlişkin Bulgular

\begin{tabular}{|c|l|c|c|}
\hline \multicolumn{2}{|c|}{ Demografik Özellikler } & f & \% \\
\hline \multirow{3}{*}{ Cinsiyet } & Kadın & 289 & 54.7 \\
\cline { 2 - 4 } & Erkek & 239 & 45.3 \\
\hline \multirow{4}{*}{ Yaş } & 20 ve altı & 86 & 16.3 \\
\cline { 2 - 4 } & $21-30$ & 214 & 40.5 \\
\cline { 2 - 4 } & $31-40$ & 107 & 20.3 \\
\cline { 2 - 4 } & $41-50$ & 75 & 14.2 \\
\cline { 2 - 4 } & 51 ve üzeri & 46 & 8.7 \\
\hline \multirow{5}{*}{ Eğitim Düzeyi } & İlköğretim & 85 & 16.1 \\
\cline { 2 - 4 } & Lise & 219 & 41.5 \\
\cline { 2 - 4 } & Önlisans & 105 & 19.9 \\
\cline { 2 - 4 } & Lisans & 10 & 20.6 \\
\cline { 2 - 4 } & Lisansüstü & 66 & 1.9 \\
\hline \multirow{2}{*}{ Meslek } & Memur & & 20.3 \\
\cline { 2 - 4 } & Serbest Meslek & 12.5 \\
\hline
\end{tabular}

July-2020 Vol:5 No:1 International Journal of Turkic World Tourism Studies 


\begin{tabular}{|l|l|l|l|}
\hline \multirow{4}{*}{} & Esnaf & 34 & 6.4 \\
\cline { 2 - 4 } & İşçi & 83 & 15.7 \\
\cline { 2 - 4 } & Emekli & 25 & 4.7 \\
\cline { 2 - 4 } & Ev Hanımı & 59 & 11.2 \\
\cline { 2 - 4 } & Öğrenci & 141 & 26.7 \\
\cline { 2 - 4 } & Diğer & 13 & 2.5 \\
\hline \multirow{5}{*}{ Aylık Gelir Düzeyi } & $1000 \mathrm{TL}$ 'den az & 150 & 28.4 \\
\cline { 2 - 4 } & $1001-2200 \mathrm{TL}$ & 130 & 24.6 \\
\cline { 2 - 4 } & $2201-4000 \mathrm{TL}$ & 70 & 29.5 \\
\cline { 2 - 4 } & $4001-6000 \mathrm{TL}$ & 22 & 13.3 \\
\cline { 2 - 4 } & $6001 \mathrm{TL}$ ve üzeri & 4.2 \\
\hline
\end{tabular}

Tablo 1'deki sonuçlara göre, katılımcıların \%54.7'si kadınlardan, \%45.3'ü erkeklerden oluşmaktadır. Katılımcıların \%16.3'ü 20 ve altı yaş grubunda yer alırken \%40.5'i 21-30, \%20.3'ü 31-40, \%14.2'si 41-50 ve \%8.7'si 51 ve üzeri yaş grubundadır. Kat1lımcıların eğitim düzeyleri incelendiğinde, \%16.1'i ilköğretim, \%41.5'i lise, \%19.9'u önlisans, \%20.6's lisans ve \%1.9'u ise lisansüstü düzeyde eğitime sahiptirler. Ayrıca, katılımcıların \%20.3'ü memurlardan, \%12.5'i serbest meslek çalışanlarından, \%6.4'ü esnaflardan, \%15.7'si işçilerden, \%4.7'si emeklilerden, \%11.2'si ev hanımlarından, \%26.7'si öğrencilerden ve \%2.5'i diğer meslek gruplarından (ağırlıklı olarak işsiz olarak belirtilmiştir) oluşmaktadır. Son olarak, katılımcıların \%28.4'ü $1000 \mathrm{TL}$ ve altı gelir grubunda yer alırken, \%24.6's1 1001-2200 TL, \%29.5'i 2201-4000 TL, \%13.3'ü 4001-6000 TL ve $\% 4.2$ 'si 6001 TL ve üzeri gelir grubunda yer almaktadır.

\section{Katılımcıların Türk Kahvesi İçme Sıklıklarına İlişkin Bulgular}

Tablo 2'de katılımcıların Türk kahvesi içme sıklıklarına ilişkin yüzde ve frekans analizi sonuçları yer almaktadir.

Tablo 2. Katılımcıların Türk Kahvesi İçme Sıklığına İlişkin Bulgular

\begin{tabular}{|c|c|c|c|}
\hline \multirow{7}{*}{ Türk Kahvesi İçme Sıklığı } & Sıklık & $\mathbf{f}$ & $\%$ \\
\hline & $\begin{array}{l}\text { Çok sık (her gün ve günde bir taneden } \\
\text { fazla) }\end{array}$ & 101 & 19.1 \\
\hline & S1k (her gün ve günde bir tane) & 120 & 22.7 \\
\hline & Genellikle (haftada en az 3 gün) & 134 & 25.4 \\
\hline & $\begin{array}{l}\text { Bazen (haftada birkaç gün aklıma } \\
\text { geldikçe) }\end{array}$ & 108 & 20.5 \\
\hline & Nadiren (ayda y1lda bir) & 59 & 11.2 \\
\hline & Asla & 6 & 1.1 \\
\hline
\end{tabular}

Tablo 2'deki sonuçlar incelendiğinde katılımcıların \%19.1'i çok sık (hergün ve günde bir taneden fazla), \%22.7'si s1k (hergün ve günde bir tane), \%25.4'ü genellikle (haftada en az 3 gün), \%20.5'i bazen (haftada birkaç gün aklıma geldikçe), \%11.2'si nadiren (ayda yılda bir) Türk kahvesi içtiklerini belirtirken \%1.1'i asla Türk kahvesi içmediklerini belirtmişlerdir. Bu sonuçlar incelendiğinde, katılımcıların büyük bir kısmı Türk kahvesini sık sık tükettikleri sonucuna varılabilir. 


\section{Tüketicilerin Türk Kahvesi Hakkındaki Bilgi Algılarını Belirlemeye Yönelik Bulgular}

Tablo 3'te katılımcıların Türk kahvesi hakkındaki bilgi algılarını belirmeye yönelik 5'li Likert ölçeğinde yöneltilmiş üç adet ifadenin yüzde, frekans, aritmetik ortalama ve standart sapma sonuçları yer almaktadır.

Tablo 3. Türk Kahvesine Yönelik Bilgi Algılarını Belirlemeye Yönelik Bulgular

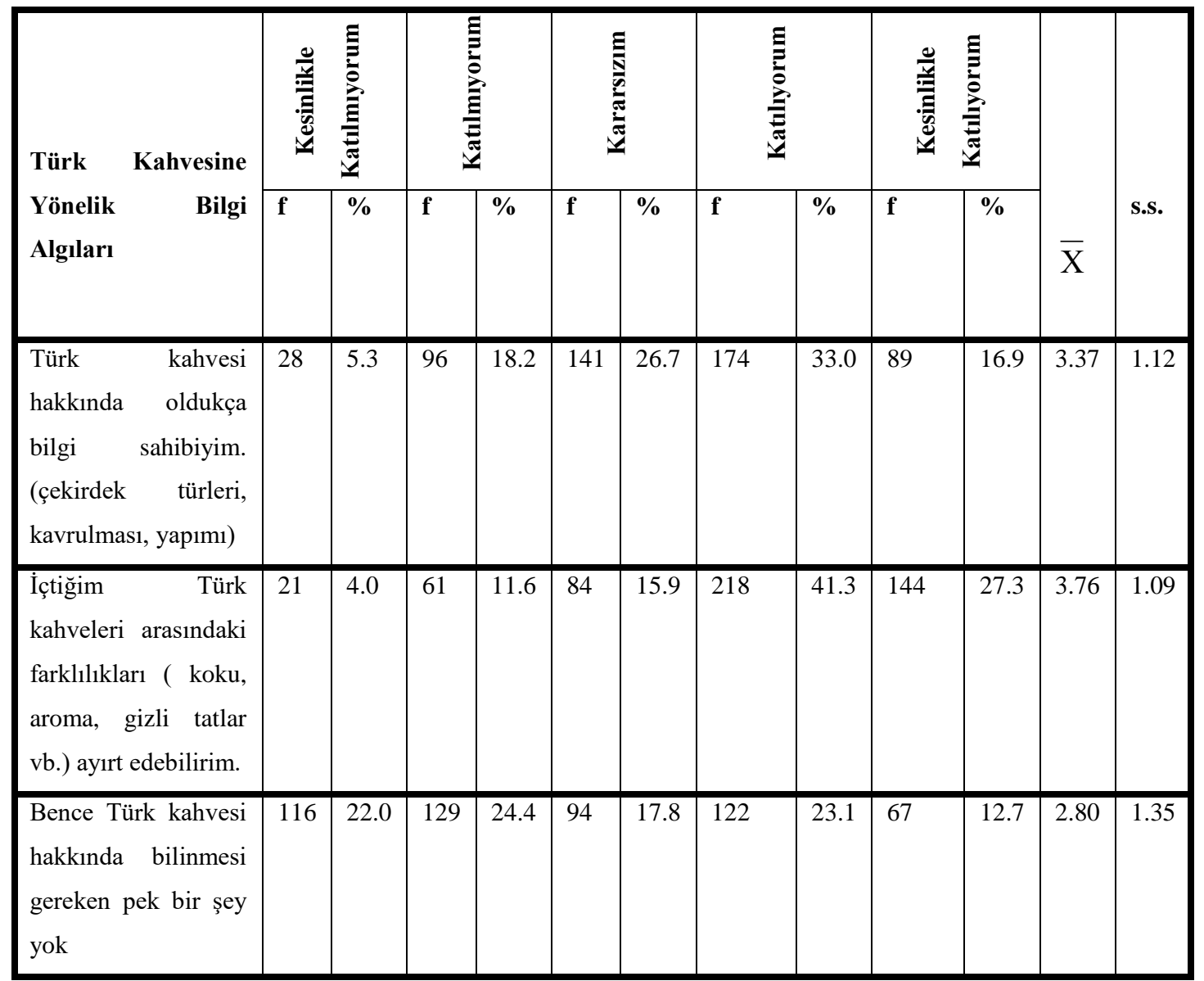

“Türk kahvesi hakkında oldukça bilgi sahibiyim (çekirdek türleri, kavrulması, yapımı)” ifadesine katılımcıların \%49.9'u olumlu yönde görüş bildirirken, $\% 23.5^{\prime} \mathrm{i}$ olumsuz yönde görüş bildirilmișlerdir. \%15.9'u ise kararsız olduklarını ifade etmișlerdir.

"İçtiğim Türk kahveleri arasındaki farklılıkları (koku, aroma, gizli tatlar v.b.) ayırt edebilirim" ifadesine katılımc1ların \%68.6's1 olumlu yönde cevap verirken, \%15.6's1 olumsuz yönde cevap vermișlerdir. \%15.9'u ise bu konuda kararsız olduklarını ifade etmektedirler.

"Bence Türk kahvesi hakkında bilinmesi gereken pek bir şey yok" ifadesine \%46.4'ü kesinlikle katılmıyorum ve katılmıyorum seçenekleri tercih ederek Türk kahvesi hakkında bilinmesi gereken şeylerin olduğunu, \%35.8'i kesinlikle katılıyorum ve katılıyorum seçeneklerini tercih ederek Türk kahvesi hakkında bilinmesi gereken pek birşey olmadığını ortaya koymaktadırlar. \%17.8'i ise bu konuda kararsız olduklarını ifade etmektedirler. 


\section{Tüketicilerin Türk Kahvesi Hakkındaki Bilgi Algıları ile Demografik Değişkenlerin ve Kahve Tüketim Sıklıklarının Karşılaştırılması}

Tablo 4'te katılımcıların Türk kahvesi hakkındaki bilgi algıları ile cinsiyetlerinin karşılaştırılmasına yönelik Bağımsız Örneklemler İçin T-testi sonuçları yer almaktadır.

Tablo 4. Tüketicilerin Türk Kahvesine Yönelik Bilgi Algıları İle Cinsiyetlerinin Karşılaştırılması

\begin{tabular}{|c|l|l|l|l|l|c|}
\hline \multicolumn{1}{|c|}{ Boyut } & Cinsiyet & $\mathbf{n}$ & $\overline{\mathrm{X}}$ & S.S. & t & p \\
\hline \multirow{2}{*}{ Bilgi Alg1S1 } & Kadın & 289 & 3.52 & 0.72 & \multirow{2}{*}{2.623} & \multirow{2}{*}{$0.009 * *$} \\
\cline { 2 - 6 } & Erkek & 239 & 3.35 & 0.70 & \\
\hline
\end{tabular}

${ }^{* * *}: \mathrm{p}<0.001 \quad * *: \mathrm{p}<0.01 \quad *: \mathrm{p}<0.05$

Yukarıdaki tabloda belirtilen sonuca göre, tüketicilerin Türk kahvesi hakkındaki bilgi algıları cinsiyetlerine göre anlamlı bir farklılık göstermektedir $(\mathrm{p}=0.009<0.05)$. Kadın tüketicilerin Türk kahvesi hakkındaki bilgi algıları erkek tüketicilere göre daha fazla olduğu ortaya çıkmaktadır.

Tablo 5'te katılımcıların Türk kahvesi hakkındaki bilgi algılarının yaş gruplarına göre anlamlı bir farklılık olup olmadığını belirlemek amacıyla yapılan ANOVA sonuçları yer almaktadır.

Tablo 5. Tüketicilerin Türk Kahvesine Yönelik Bilgi Algıları İle Yaş Gruplarının Karşılaştırılması

\begin{tabular}{|c|c|c|c|c|c|c|c|}
\hline Boyut & $\begin{array}{c}\text { Yaş } \\
\text { Aralığı }\end{array}$ & $\mathbf{n}$ & $\bar{X}$ & S.S. & $\mathbf{F}$ & $\mathbf{p}$ & $\begin{array}{c}\text { Çoklu } \\
\text { Karşılaştırma }\end{array}$ \\
\hline \multirow{5}{*}{$\begin{array}{l}\text { Bilgi } \\
\text { Alg1s1 }\end{array}$} & 20 ve alt 1 & 86 & 3.37 & 0.70 & \multirow{5}{*}{0.388} & \multirow{5}{*}{0.817} & \multirow{5}{*}{-} \\
\hline & $21-30$ & 214 & 3.48 & 0.74 & & & \\
\hline & $31-40$ & 107 & 3.42 & 0.76 & & & \\
\hline & $41-50$ & 75 & 3.43 & 0.69 & & & \\
\hline & 51ve üzeri & 46 & 3.48 & 0.58 & & & \\
\hline
\end{tabular}

${ }^{* * *}: \mathrm{p}<0.001{ }^{* *}: \mathrm{p}<0.01 \quad *$ : $<<0.05$

Tablo 5'teki sonuçlara göre, tüketicilerin Türk kahvesi hakkındaki bilgi algıları ile yaş grupları arasında anlamlı bir farklılık yoktur $(\mathrm{p}=0.817>0.05)$.

Tablo 6'da katılımcıların Türk kahvesi hakkındaki bilgi algılarının eğitim düzeylerine göre anlamlı bir farklılık olup olmadığını belirlemek amacıyla yapılan ANOVA sonuçları yer almaktadır.

Tablo 6. Tüketicilerin Türk Kahvesine Yönelik Bilgi Algıları İle Eğitim Düzeylerinin Karşılaştırılması

\begin{tabular}{|c|c|c|c|c|c|c|c|}
\hline Boyut & $\begin{array}{l}\text { Ĕgitim } \\
\text { Düzeyi }\end{array}$ & $\mathbf{n}$ & $\bar{X}$ & S.S. & $\mathbf{F}$ & $\mathbf{p}$ & $\begin{array}{c}\text { Çoklu } \\
\text { Karşılaştırma }\end{array}$ \\
\hline \multirow{5}{*}{$\begin{array}{l}\text { Bilgi } \\
\text { Alg1S1 }\end{array}$} & İlköğretim & 85 & 3.32 & 0.62 & \multirow{5}{*}{3.031} & \multirow{5}{*}{$0.017 *$} & \multirow{5}{*}{$2-4$} \\
\hline & Lise & 219 & 3.37 & 0.71 & & & \\
\hline & Önlisans & 105 & 3.54 & 0.70 & & & \\
\hline & Lisans & 109 & 3.60 & 0.77 & & & \\
\hline & Lisansüstü & 10 & 3.36 & 0.85 & & & \\
\hline
\end{tabular}

${ }^{* * *}: \mathrm{p}<0.001{ }^{* *}: \mathrm{p}<0.01 \quad *$ : $<0.05$ 
Yukarıdaki tabloda yer alan sonuçlara göre, tüketicilerin Türk kahvesi hakkındaki bilgi algıları eğitim düzeylerine göre anlamlı bir farklılık göstermektedir $(\mathrm{p}=0.017<0.05)$. Farklılıkların hangi ikili gruplardan kaynaklandığını belirlemek amacıyla yapılan Çoklu Karşılaştırma Testi sonuçları incelendiğinde, lisans düzeyinde eğitime sahip tüketicilerin, lise düzeyinde eğitime sahip tüketicilere göre Türk kahvesi hakkındaki bilgi algıları daha yüksektir. Bu analizdeki diğer bir sonuç ise, eğitim düzeyi arttıkça (lisansüstü göz ardı edilerek) tüketicilerin Türk kahvesi hakkındaki bilgi algı düzeyleri de artmaktadır.

Tablo 7'de katılımcıların Türk kahvesi hakkındaki bilgi algılarının mesleklerine göre anlamlı bir farklılık olup olmadığını belirlemek amacıyla yapılan ANOVA sonuçları yer almaktadır.

Tablo 7. Tüketicilerin Türk Kahvesine Yönelik Bilgi Algıları İle Mesleklerin Karşılaştırılması

\begin{tabular}{|c|c|c|c|c|c|c|c|}
\hline Boyut & Meslek & $\mathbf{n}$ & $\overline{\mathrm{X}}$ & S.S. & $\mathbf{F}$ & $\mathbf{p}$ & $\begin{array}{c}\text { Çoklu } \\
\text { Karşılaştırma }\end{array}$ \\
\hline \multirow{8}{*}{$\begin{array}{l}\text { Bilgi } \\
\text { Algisi }\end{array}$} & Memur & 107 & 3.55 & 0.72 & \multirow{8}{*}{1.213} & \multirow{8}{*}{0.294} & \multirow{8}{*}{ - } \\
\hline & Serbest Mes. & 66 & 3.42 & 0.66 & & & \\
\hline & Esnaf & 34 & 3.28 & 0.84 & & & \\
\hline & İşçi & 83 & 3.44 & 0.66 & & & \\
\hline & Emekli & 25 & 3.41 & 0.68 & & & \\
\hline & Ev Hanımı & 59 & 3.27 & 0.72 & & & \\
\hline & Öğrenci & 141 & 3.48 & 0.75 & & & \\
\hline & Diğer & 13 & 3.53 & 0.66 & & & \\
\hline
\end{tabular}

Tablo 7'deki sonuçlara göre, tüketicilerin Türk kahvesi hakkındaki bilgi algıları ile meslekleri arasında anlamlı bir farklılık yoktur $(\mathrm{p}=0.294>0.05)$.

Tablo 8'de katılımcıların Türk kahvesi hakkındaki bilgi algılarının aylık gelir düzeylerine göre anlamlı bir farklılık olup olmadığını belirlemek amacıyla yapılan ANOVA sonuçları yer almaktadır.

Tablo 8. Tüketicilerin Türk Kahvesine Yönelik Bilgi Algıları İle Aylık Gelir Düzeylerinin Karşılaştırılması

\begin{tabular}{|c|c|c|c|c|c|c|c|}
\hline Boyut & Aylık Gelir & $\mathbf{n}$ & $\bar{X}$ & S.S. & $\mathbf{F}$ & $\mathbf{p}$ & $\begin{array}{c}\text { Çoklu } \\
\text { Karşılaştırma }\end{array}$ \\
\hline \multirow{5}{*}{$\begin{array}{l}\text { Bilgi } \\
\text { Alg1S1 }\end{array}$} & 1000 TL'den az & 150 & 3.45 & 0.69 & \multirow{5}{*}{0.195} & \multirow{5}{*}{0.941} & \multirow{5}{*}{-} \\
\hline & $1001-2200 \mathrm{TL}$ & 130 & 3.44 & 0.69 & & & \\
\hline & $2201-4000 \mathrm{TL}$ & 158 & 3.46 & 0.73 & & & \\
\hline & $4001-6000 \mathrm{TL}$ & 70 & 3.38 & 0.75 & & & \\
\hline & $\begin{array}{lll}6001 & \text { TL } & \text { ve } \\
\text { üzeri } & & \end{array}$ & 22 & 3.48 & 0.86 & & & \\
\hline
\end{tabular}

Tablo 8'deki sonuçlara göre, tüketicilerin Türk kahvesi hakkındaki bilgi algıları ile aylık gelir düzeyleri arasında anlamlı bir farklılık yoktur $(\mathrm{p}=0.941>0.05)$.

Tablo 9'da katılımcıların Türk kahvesi hakkındaki bilgi algılarının Türk kahvesi içme sıklıklarına göre anlamlı bir farklılık olup olmadığını belirlemek amacıyla yapılan ANOVA sonuçları yer almaktadir. 
Tablo 9. Tüketicilerin Türk Kahvesine Yönelik Bilgi Algıları İle Türk Kahvesi İçme Sıklıklarının Karşılaştırılması

\begin{tabular}{|c|c|c|c|c|c|c|c|}
\hline Boyut & $\begin{array}{l}\text { Türk Kahvesi } \\
\text { İçme Sıklığı }\end{array}$ & $\mathbf{n}$ & $\bar{X}$ & s.s. & $\mathbf{F}$ & $\mathbf{p}$ & $\begin{array}{c}\text { Çoklu } \\
\text { Karşılaştırma }\end{array}$ \\
\hline \multirow{6}{*}{$\begin{array}{l}\text { Bilgi } \\
\text { Algis1 }\end{array}$} & $\begin{array}{l}\text { Çok sik (her gün } \\
\text { ve günde bir } \\
\text { taneden fazla) }\end{array}$ & 101 & 3.74 & 0.70 & \multirow{6}{*}{10.133} & \multirow{6}{*}{$0.000 * * *$} & \multirow{6}{*}{$\begin{array}{c}1-3 \\
1-4 \\
1-5 \\
2-4,5 \\
3-5\end{array}$} \\
\hline & $\begin{array}{l}\text { Sik (her gün ve } \\
\text { günde bir tane) }\end{array}$ & 120 & 3.56 & 0.63 & & & \\
\hline & $\begin{array}{l}\text { Genellikle } \\
\text { (haftada en az } 3 \\
\text { gün) }\end{array}$ & 134 & 3.46 & 0.68 & & & \\
\hline & $\begin{array}{lr}\text { Bazen } & \text { (haftada } \\
\text { birkaç } & \text { gün } \\
\text { aklıma } & \text { geldikçe) }\end{array}$ & 108 & 3.21 & 0.77 & & & \\
\hline & $\begin{array}{l}\text { Nadiren } \\
\text { y1lda bir) }\end{array}$ & 59 & 3.08 & 0.63 & & & \\
\hline & Asla & 6 & 3.27 & 0.53 & & & \\
\hline
\end{tabular}

Yukarıda yer alan sonuçlara göre, tüketicilerin Türk kahvesi hakkındaki bilgi algıları ile Türk kahvesi içme sıklıkları arasında anlamlı bir farklılık vardır $(\mathrm{p}=0.941>0.001)$. Buna göre, Türk kahvesi içme sıklığı azaldıkça (asla seçeneğini tercih edenler göz ardı edilerek) Türk kahvesi hakkındaki bilgi algıları da azalmaktadır.

\section{Sonuç ve Öneriler}

Yapılan araştırmalar göstermektedir ki, bu derece köklü bir geçmişe sahip olan ve Türk mutfağının en önde gelen içeceklerinden biri olan Türk kahvesi, küreselleşmenin olumsuz etkilerine karş1 savunmasız kalmıștır. Günümüzde gençler küresel kahve zincirlerinde Batılı yöntemlerle hazırlanan yeni kahveleri daha çok tercih etmekte ve Türk kahvesine daha az ilgi göstermektedir. Geleneksel kahvehaneler yok denecek kadar azalmakta, böylesine zengin bir kültürün yaşamasını ve gelecek kuşaklara aktarılmasını tehlikeye sokmaktadır. Bu tehlikenin önlenebilmesi için Türk kahvesine önem verilmeli ve sahip çıkılmalıdır. Türk kahvesinin tarihi, yapısı, özellikleri, hazırlanma ve servis süreçleri ile ilgili bilgi sahibi olunmalıdır.

$\mathrm{Bu}$ yönde yapılması gereken ilk girişimlerden biri de öncelikle Türk kahvesi hakkında bilgi seviyesinin artırılmasıdır. Görüldüğü üzere bu oldukça kapsamlı, meşakkatli ve süreli bir amaçtır ve sonuca başarıyla ulaşılabilmesi için bir dizi faaliyet gerekmektedir. Bilgi düzeyinin artırılması yönünde yapılacak tüm planlar, projeler, mesleki eğitimler, vb'den önce ilkin bir durum tespiti yapılmalı ve Türk kahvesi tüketicilerinin ne kadar bilgiye sahip oldukları belirlenmelidir. Bu nedenle bu çalışma, ilk aşamada Türk kahvesi tüketicilerinin Türk kahvesi üzerine sahip olduklarını düşündükleri bilgi düzeyini (algılanan bilgi düzeyi) tespit etmiştir. Bundan sonraki aşamalarda, Türk kahvesi hakkında sahip olunan gerçek bilgi seviyesini, tüketicilerin kahve içme motivasyonlarını ve yiyecek içecek işletmelerinde servis edilen Türk kahvesi hakkındaki memnuniyet seviyesini ölçmeye yönelik çalışmalarla konu daha kapsamlı şekilde ele alınacak ve Türk kahvesi hakkında farkındalığın artırılmasına yönelik çalışmalar yapılacaktır. 
Tüketicilerin Türk kahvesi üzerine algıladıkları bilgi düzeyini ölçmeye yönelik yapılan bu çalışmada yaş grubunun, mesleğin ve aylık gelirin bilgi algısı üzerinde anlamlı bir etkisi olmadığı saptanmıştır. Yani farklı yaş grubundan, meslekten ya da aylık gelir grubundan herhangi bir tüketicinin bilgi algısı açısından öne çıkmadığı, genel olarak her yaş, meslek ve gelir grubuna ait Türk Kahvesi tüketicilerinin ortalama düzeyde bilgi düzeyine sahip olduklarını algıladıkları görülmüştür.

$\mathrm{Bu}$ çalışmada ortaya çıkan bulgulardan bir tanesi de kadın tüketicilerin Türk kahvesi hakkındaki bilgi algılarının erkek tüketicilere göre daha fazla olduğudur. Bir diğer deyişle kadın Türk kahvesi tüketicileri, erkeklere oranla kahve hakkında daha fazla bilgiye sahip olduklarını düşünmektedirler. Araştırmada saptanan bir diğer bulgu da eğitim düzeyi arttıç̧a Türk kahvesi tüketicilerinin kahve üzerine daha fazla bilgiye sahip olduklarını düşünmeleridir. Çalışma Türk kahvesi hakkındaki bilgi algısı ile Türk kahvesi içme sıklığı arasında da anlamlı bir farklılık saptamıştır. Bu sonuca göre, Türk kahvesini daha çok ve sık tüketen tüketici gruplarının Türk kahvesi üzerine daha fazla bilgi sahibi olduklarını düşündügü belirlenmiştir.

$\mathrm{Bu}$ araştırmanın sonuçları, Türk kahvesi tüketicilerinin Türk kahvesi hakkında (kavrulması, pişirilmesi, sunumu vb.) bilgi sahibi olduğunu düşündüklerini ortaya koymuştur. Özellikle kadınların, eğitim düzeyi daha yüksek tüketicilerin ve daha sık Türk kahvesi tüketen tüketicilerin diğer gruplara oranla daha fazla bilgi düzeyi algısına sahip oldukları görülmüşsür. Peki bu gerçekten böyle midir? Türk kahvesi tüketicileri içtikleri kahvenin tarihi, çekirdeği, menşei, kavrulma yöntemleri, pişirilmesi, sunumu ve Türk kahvesinin şahsına münhasır pek özelliği hakkında gerçekten bilgi sahibi midir? Bu soruların yanıtları henüz bilinmiyor ancak bu çalışmanın ortaya koyduğu durum tespitinden sonra yapılacak bir dizi araştırmayla belirlenmesi beklenmektedir. Dolayısıyla bu çalışma kendisinden sonra gelecek pek çok çalışmaya öncül oluşturmakta ve ilerleyen araştırmalarla desteklenmelidir. Böylelikle Türk kahvesi üzerine sahip olunan bilgi düzeyi artırılabilir ve Türk kahvesi bir yandan ulusal kimlik olma görevini üstelenmeye devam ederken bir yandan da Batılı rakiplerine karşı mevcudiyetini koruyabilir.

\section{Kaynakça}

Akarçay, E. (2012). Kâh kahvehane kâh cafe: küreselleşen Eskişehir'de kahve tüketimi üzerine kurumsal bir giriş [Özel Say1]. Aynalı Labirent Küreselleşen Kentte Tüketim, (s.181-202). İstanbul: Galatasaray Üniversitesi İletişim Dergisi, 2.

Akşit Aşık, N. (2017). Değişen Kahve Tüketim Alışkanlıkları ve Türk Kahvesi Üzerine Bir Araştırma. Journal of Tourism and Gastronomy Studies, 5 (4), 310-325.

Alagözlü, N. (2007). Bir Söylem Türü Olarak Kahve Falına Yönelik Bir İnceleme: Kahve Falı ve İdeoloji. Hacettepe Üniversitesi Edebiyat Fakültesi Dergisi, 24 (1), 1-22.

Atlı, H.F. (2018). Kahve Pazarlaması ve Türk Kahvesinin Ekonomik, Sosyal ve Kültürel Özelliklerinin Değerlendirilmesi. Akademik Sosyal Araştırmalar Dergisi, 6 (84), 413-424.

Aydın, Adalı, G. \& Bakır, Z., N. (2016). An Assessment of Venues in the Context of Consumption Culture: Consumption of Kahve Cafe(s) by College Students. Journal of Strategic Research in Social Science, $2(3), 59-84$.

Bulduk, S. \& Süren, T. (2007). Türk Mutfak Kültüründe Kahve, 38. ICANAS (Uluslararası Asya ve Kuzey Afrika Çalı̧̧maları Kongresi. (s. 299-309). Ankara.

July-2020 Vol:5 No:1 International Journal of Turkic World Tourism Studies 
Giritlioğlu, İ. \& Gündoğan, H.R. (2017). Kafe ve Pastane İşletmelerini Ziyaret Eden Müşterilerin Tüketim Alışkanlıklarına Yönelik Bir Araştırma. Çukurova Araştırmaları Dergisi, 3 (2), 165-171.

Gürsoy, D. (2013). Tarihin Süzgecinde Mutfak Kültürümüz. İstanbul: Oğlak Yayınc1lık.

Hattox, R. S. (1996). Kahve ve Kahvehaneler Bir Toplumsal İçeceğin Yakındoğu'daki Kökeni. İstanbul: Türkiye Ekonomik Ve Toplumsal Tarih Vakfi.

Heise U. (2001). Kahve ve Kahvehane. (M. Tüzel, Çeviri). Ankara: Dost Yayınları.

Koç, B. (2016). Bingöl Üniversitesi Öğrencilerinin Hazır Kahve Tüketimi İle İlgili Tutum ve Davranışları. XII. Ulusal Tarım Ekonomisi Kongresi (s.519-524). Isparta.

Malaguzzi, S. (2008). Food and Feasting in Art. California: Getty Publications.

Sözlü, S., Yılmaz, B. \& Acar Tek, N. (2017). Kahve Tüketimi ve Bazı Hastalıklarla İlişkisi. SDÜ Sağlık Bilimleri Enstitüsü Dergisi, 8 (2), 33-39.

Tansuğ, S. (1995). Eski İstanbul'da Kahve İkram Töreni. İstanbul Armağanı, içinde (s. 161-166). İstanbul: Kültür İşleri Daire Başkanlığı.

Tufan, E. (2019). Türk kahvesi tüketici tipolojisi: keşifsel bir yaklaşım (Yayınlanmamış Yüksek Lisans Tezi). Adnan Menderes Üniversitesi Sosyal Bilimler Enstitüsü, Aydın.

Yaşar, A. (2005). Osmanlı Şehir Mekânları: Kahvehane Literatürü. Türkiye Araştırmaları Literatür Dergisi, 3 (6), 237-256.

Yılmaz, E., Oraman, Y., Özdemir, G., Arap, S. \& Yılmaz İ. (2016). Türk Kahvesi Tüketim Eğilimleri ve Tüketici Özelliklerinin Belirlenmesi, XII. Ulusal Tarım Ekonomisi Kongresi (s. 457-473). Isparta.

https://coffee.digital/kultur-detay/turk-kahvesi-gununde-turk-kahvesi-derneginden-bazi-istatistikler

http://www.karmaliz.com/2017/03/kahve-zincirleri-rekabeti.html

http://www.ico.org/prices/new-consumption-table.pdf

July-2020 Vol:5 No:1 International Journal of Turkic World Tourism Studies 